\title{
TNNI3 Gene
}

National Cancer Institute

\section{Source}

National Cancer Institute. TNNI3 Gene. NCI Thesaurus. Code C104223.

This gene is involved in cardiac muscle contraction. 